\title{
CORINTH IN THE FIRST CENTURY AD: THE SEARCH FOR ANOTHER ClASS
}

\author{
Dirk Jongkind
}

\begin{abstract}
Summary
A consideration of living spaces in ancient Corinth suggests that it is not possible to characterise its society as one made up merely of a very small number of élite alongside vast numbers of non-élite who were extremely poor. The variety of housing suggests the existence of another class.
\end{abstract}

\section{Introduction}

The city of Corinth had a glorious Hellenic past before its destruction by the Romans in $146 \mathrm{BC}$. Yet when it was refounded in $44 \mathrm{BC}$, it was not rebuilt as a Greek city, but as a Roman colony. Due to its economically strategic position near the Isthmus, the city prospered under Roman emperors. The apostle Paul wrote letters to the church of this city. According to some scholars (Theissen, Judge, Meeks), class-distinctions and social tensions within the church played a major role in the background against which Paul wrote. Though it is admitted that the Corinthians, like others, had 'the poor always with them', it is also argued from primary evidence that a portion of the Corinthian church belonged to the upper class.

This view has recently received heavy criticism from Justin Meggitt, who in his comprehensive and lucid study Paul, Poverty, and Survival divides Roman society into essentially two groups: the élite and non-élite. The latter led a life just above starvation level: 'In their experience of housing, as well as in their access to food and clothing, the Greco-Roman non-élite suffered a subsistence or near subsistence life.' ${ }^{1}$ According to Meggitt, this non-élite group comprised more than

1 Justin J. Meggitt, Paul, Poverty and Survival (Edinburgh: T\&T Clark, 1998), 66-67. 
$99 \%$ of the Graeco-Roman society. ${ }^{2}$ It is proposed to examine to what extent Meggitt's dichotomous classification of Roman society is justified when we look at the archaeological evidence of domestic space. ${ }^{3}$ Because the Corinthian correspondence is central both to those who defend and to those who reject the presence of the non-poor in the church, it is important to take a closer look at the setting by scanning the remaining archaeological evidence in Corinth. ${ }^{4}$

The Roman character of Corinth gives ample opportunity to compare it with other Roman cities such as Pompeii. That city provides a rich source for archaeological parallels to first-century Corinth because not only is it Roman, as Corinth essentially was, but it is more or less completely preserved. The actual buildings in Corinth are badly preserved: subsequent earthquakes and rebuilding have left us with little more than foundations. Neither is it possible, despite nearly a century of excavation, to reconstruct plans of complete or nearly complete quarters or larger blocks of houses.

\section{Centuriation}

Roman colonies were designed according to the centuriation pattern, in which the land was marked out in squares and rectangles, normally prior to distribution. ${ }^{5}$ It has been clearly established that this system was used at the refounding of Corinth. ${ }^{6}$ The squares and rectangles were called insulae. These insulae measured $1 \times 1$ to $1 \times 4 a c t i^{7}$ and were separated from one another by roads.

A complete Corinthian insula has yet to be excavated, but east of the theatre an area of roughly $10 \times 40$ metres has been uncovered. The shops and houses found here did not form part of one contiguous

2 Meggitt, Paul, Poverty, 50, esp. n. 49. The author criticises Rohrbaugh's estimation that the élite constituted $5-10 \%$ of the population and holds to a figure of less than $1 \%$, all the rest being assigned to 'abject poverty'.

3 We leave aside the work by Donald Engels on Corinth who argues on economic grounds for relatively high wealth of the average peasant. See Engels, Roman Corinth: An Alternative Model for the Classical City (Chicago, London: University of Chicago, 1990), 29-30.

4 Proving or disproving Meggitt's thesis of a large, extremely poor non-élite, does not automatically impact on the validity of the claims of his opponents (labelled by him as the 'New Consensus').

5 Michael H. Crawford, 'Centuriation', Oxford Classical Dictionary, 310.

6 David Gilman Romano, 'Post-146 B.C. Land Use in Corinth, and Planning of the Roman Colony of 44 B.C.', in The Corinthia in the Roman Period, Timothy E. Gregory ed. (Ann Arbor, Mi.: Journal of Roman Archaeology, 1994), 9-30.

7 One actus is 120 feet (app. $120 \times 29.5 \mathrm{~cm}=34.5 \mathrm{~m}$ ). 
block; behind the northern row of shops a service road was found separating them from a large house of which only a few rooms were excavated. ${ }^{8}$ Also the terrain rises here to the south which made it difficult to construct large, contiguous buildings. This means that though the land may have been given out per insula, the building erected on a plot did not need to occupy the whole insula. Neither does the existence of these city-plan insulae mean that in Corinth the large, multi-storey apartment buildings existed, which we know from Rome, Ostia, and Ephesus and are also known as insulae. ${ }^{9}$ Variation in the use of the land of one city block existed. The Roman colony of Ptolemais (Cyrenaica), for example, was set up in a similar manner to Corinth and here we find several large houses occupying one insula together. Likewise, in the colony of Timgad founded by Trajan we find two single-storey houses on an insula of 70 feet square. Sometimes a single house can even combine two insulae. ${ }^{10}$

\section{Types of Living Space}

\section{The Insula}

There is as yet no archaeological evidence for the existence of large apartment blocks in Corinth because excavations has been confined largely to the forum area. The epigraphic evidence which may indicate that larger apartment blocks were built in the area, are two inscriptions connected to a certain Priscus. Kent has published an inscription from the provincial governor, found near the south stoa on the forum, in which permission is given for the selling of land on the Isthmia to Priscus in order to build fifty oikol. 11 This permission is granted on the condition that these oil kor are available for athletes during the Isthmian games for free. Broneer translates oíkor in this context as 'rooms',12 while Kent opts for 'dwelling units'. Priscus lists all his

8 Charles K. Williams and Orestes H. Zervos, 'Corinth, 1982: East of the Theatre', Hesperia 52 (1983) 1-47, esp. 13.

9 Augustus restricted the maximum height for an insula in Rome to 70 feet. Strabo, Geogr. 5.3.7; Suetonius, Vit. Aug. 89.2.

10 Alexander Gordon McKay, Houses, Villas and Palaces in the Roman World (London: Thames and Hudson, 1975), 226-31.

11 John Harvey Kent, The Inscriptions, 1926-1950 Corinth; Vol. 8 Pt. 3 (Princeton, N.J.: American School of Classical Studies at Athens, 1966), 119-22.

12 Oscar Broneer, 'An Official Rescript from Corinth', Hesperia 8 (1939) 181-90. See also L. Robert, Un édifice du sanctuaire de l'Isthme dans une inscription de Corinthe', Hellenica 1 (1940) 43-53. 
benefactions on another inscription and mentions the building of the rooms for the athletes. ${ }^{13}$ The idea is clearly of a larger building or buildings containing 50 apartments. The two inscriptions are dated to the second century AD, which diminishes their importance for our topic as the use of the multi-storey apartment blocks became more widespread after the first century. ${ }^{14}$

Pompeii does not seem to have had many buildings of more than two floors, ${ }^{15}$ but they could be found in the East Empire; two insulae were excavated in Ephesus and we have literary evidence for them in other places as well. ${ }^{16}$

\section{The Cenaculum}

The absence of tangible evidence for apartment blocks in Corinth does not mean that no remains of habitations of the non-élite have been found. East of the theatre four buildings have been excavated and the results of these excavations were published (1982-90). ${ }^{17}$

At least two of the four buildings were two storeys high but probably all four had a second floor at the end of the first century AD. ${ }^{18}$ The ground floor of buildings 1 and 3 were used as shops, ${ }^{19}$ while buildings 5 and 7 possibly had a domestic use. The first two form a pair and were first built between $A D 12$ and 77; the last two buildings belong to the last quarter of the first century AD..$^{20}$ Wall painting was found in destruction debris near the east wall of buildings 1 and 3, but it is uncertain whether this painting belonged to these buildings or to another structure nearby. Certain is that the upper floor of the south room of building 3 contained a room with wall-

13 IG IV, 203. Priscus did this in fulfilment of his promises made for the position of aedile ( $\dot{\alpha} \gamma o \rho \alpha v o \mu i \alpha)$.

14 Carolyn Osiek and David Balch, Families in the New Testament World: Households and House Churches (Louisville, Ky.: Westminster/John Knox, 1997), 20-24.

15 One of the notable exceptions being the Sarno Bath complex in region VIII.

16 Strabo mentions Tyre; Geogr. 16.2.23.

17 By Charles K. Williams and Orestes H. Zervos in the Hesperia volumes for the relevant years. One article on the wall-painting found during these sessions appeared elsewhere: Laura M. Gadbery, 'Roman Wall-painting at Corinth: New Evidence from East of the Theatre', in The Corinthia in the Roman Period, Timothy E. Gregory ed. (Ann Arbor, Mi.: Journal of Roman Archaeology, 1993).

18 Initially Williams and Zervos suggested two or three floors ('Corinth, 1985', Hesperia 55 [1986] 131).

19 They were used to sell food to the theatre public; in the south-west room of building $3170 \mathrm{~kg}$ of animal bones were found.

20 Williams and Zervos, 'Corinth, 1987: South of Temple and East of the Theatre', Hesperia 57 (1988) 127. 
painting, and also the buildings 5 and 7 had rooms with sometimes extensive wall decoration. This last building had at least seven rooms, of which a block of two was later converted into a separate unit with its own door to the street. Room 1 of this newly formed apartment seems to have been used as a kind of washing room, given the spout opening to the street. ${ }^{21}$ The back room had only blind walls and so must have been very dark. Although the excavators believe that building 7 had a second floor no stairs have yet been found. These may be in the unexcavated part of the house, ${ }^{22}$ or there may have been stairs directly from the street as can be seen in Pompeii. 23

The size of building 7 is comparable with for example unit 10 from the Pompeian Insula Arriana Polliana VI 6, the last-mentioned probably being advertised for rent. ${ }^{24}$ Some differences in the plan of these houses exist: the Pompeian one is built around a central space, which was not the case in building 7 , and the Pompeian unit was part of a full-sized city block. Andrew Wallace-Hadrill has made an extensive study of the typology of the various dwelling units in Pompeii and found that a useful distinction could be made on the basis of size. Buildings 5 and 7 both fall in Wallace-Hadrill's 'type 2' houses, of which the majority in Pompeii were shops. ${ }^{25}$ This category of house, smaller than the average atrium-house, has as a common feature-'the lack of any regular plan'.

\section{The Domus}

At least three larger houses that can be dated to the early Imperate have been excavated in Corinth: the houses at Anaploga, near the Sicyonian gate, and east of the theatre. ${ }^{26}$ The first one is partially published by Miller and follows the pattern of a normal Roman villa

21 Williams and Zervos, 'Corinth, 1987', 125.

22 Williams and Zervos, 'Corinth, 1988: East of the Theatre', Hesperia 58 (1989) 7-8.

23 Felix Pirson, 'Rented Accommodation at Pompeii: The Evidence of the Insula Arriana Polliana VI.6', in Domestic Space in the Roman World: Pompeii and Beyond, Ray Laurence and Andrew Wallace-Hadrill, eds. (Portsmouth, R.I.: Journal of Roman Archaeology, 1997), 171-72.

24 Pirson, 'Rented Accommodation at Pompeii', 172.

25 Andrew Wallace-Hadrill, 'Houses and Households: Sampling Pompeii and Herculaneum', in Marriage, Divorce, and Children in Ancient Rome, Beryl Rawson, ed. (Oxford: Clarendon, 1991), 210-12.

26 The last one was partially excavated in 1925 but is left out in James Wiseman, 'Corinth and Rome I: 228 B.C.-A.D. 267', ANRW: Principat II,7,1 (Berlin, New York: Walter de Gruyter, 1979). 
with an atrium, a large triclinium and several other rooms. ${ }^{27}$ Besides the triclinium, little can be said about the specific function of the other rooms except the kitchen/latrine. From Pompeian parallels it is known that sometimes parts of such houses were rented out, but nothing in the plan of this house gives any indication of this. The second house is known for its magnificent mosaic floors, but nothing has been published that makes it possible to draw any conclusions on its size and use. The last house mentioned stood very close to the four buildings described in the previous paragraphs. Though this house has been only partially excavated, the number of its rooms and its layout suggest an occupier of considerable wealth. North of temple $E$ an atrium-like building was found as well, but it is uncertain whether it had a cultic or domestic function.

\section{The Use of Houses}

Vitruvius' comment on the public function of the house of the patron is well known and often quoted:

For into the private rooms no one can come uninvited, such as the bedrooms, dining-rooms, baths and other apartments which have similar purposes. The common rooms are those into which, though uninvited, persons of the people can come in by right, such as vestibules, courtyards, peristyles and other apartments of similar uses. Therefore magnificent vestibules and alcoves and halls are not necessary to persons of a common fortune, because they pay their respect by visiting among others, and are not visited by others. 28

This description by Vitruvius is important for several reasons. First, it is worth noticing that the areas of a house are divided into public and private. And secondly, this distinction is present also in the houses of the people of 'common fortune', albeit that, in Vitruvius' opinion, those people do not need magnificent public rooms. This distinction can be seen in any of the shops in Pompeii with more than one room: the back room or cenaculum upstairs is used as private space, while the shop has a public function. When this is applied to the four buildings in Corinth, east of the theatre, it appears that the rooms numbered 1 of buildings 1 and 3 both had a public function, as they functioned probably as the room from which products were sold. The southern rooms of these houses are more difficult to interpret, though

27 The measurements of the mosaic of this room are given by Miller as $9.25 \mathrm{x}$ 5.14-5.23.

28 Vitruvius De Arch. 6.5.1 (translation taken from Loeb Classical Library). 
at a certain stage the south room of building 3 may have been used as a storage room for the shop, as it contained a lot of animal bones. ${ }^{29}$

The villas found in Corinth certainly reflect the high status of their occupants. Yet this does not mean that the nuclear family and the slaves were the only people living in the houses. Wallace-Hadrill draws attention to the contribution of legal texts for our understanding of the Roman house. ${ }^{30}$ The Digest of Justinian discusses, in the context of the difference between the right to use and the right to profit from the produce, whether a person granted with the right to use a house may also bring in other persons. Ulpian ${ }^{31}$ comments that such a person may live there with his slaves and entertain a guest. His freedmen may be brought in as well. Labeo holds 'that a man who is himself living in the house can take in a lodger'. The right to use a house included according to Paulus the right to bring in one's clients. ${ }^{32}$ Wallace-Hadrill draws the following picture on the basis of the legal textbook cases:

Alongside the familiar figure of the paterfamilias surrounded by his family and slaves, we are invited to imagine widows, freedmen, heirs, and legatees anxious to exploit urban property for the rich range of opportunities it offered: on the one hand habitation, whether for gracious living with frescos, statutes, gardens, and private baths, or as lodging for a motley crowd of dependants, freedmen, employees, clients, and visitors; on the other hand, profit, from lodgers, shops, fulleries, warehouses, and baths to let. ${ }^{33}$

The Pompeian archaeological evidence coheres with the picture that emerges from the legal sources.

This proposal influences the manner in which we envisage the way the larger houses may have functioned. It strengthens the idea of public use of the atrium and other circulation spaces, as most rooms could be accessed through these. In this respect the importance of renting out parts of the house as traceable in Pompeii must be noted. Some of the smaller cenaculae on the second floor could be reached by outdoor stairs. ${ }^{34}$ But other parts of a house were rented as well.

29 The products were most likely sold through a street-facing counter. The bench found in shop 1 may have been for private use.

30 Wallace-Hadrill, 'Houses and Households', 191-227, esp. pp. 216-18.

31 Digest 7.8.2. The translation used is Alan Watson, ed., The Digest of Justinian (Philadelphia: University of Pennsylvania, 1998).

32 Digest 7.8.3.

33 Wallace-Hadrill, 'Houses and Households', 217-18.

34 Wallace-Hadrill, 'Houses and Households', 220. A ratio of just over $10 \%$ is given for Pompeii but a higher percentage (15\%) for Herculaneum is noted. 
This is evidenced in graffiti which offered for rent parts of large and prestigious blocks. ${ }^{35}$

In Corinth, the second floor of the shops east of the theatre may well have been used to provide living space, as the wall-painting of building 3 seems to indicate. ${ }^{36}$ The fresco in the large room 4 of building 7 may indicate that the ground floor was intended for a richer household.

\section{The Poor}

Meggitt has rightly drawn attention to the living conditions of the very poor. Though it may be that he understates the living conditions of the average inhabitant of a city, it is true that those who slept on the street, under the stairs of apartment houses, or in shanties will have left very few archaeological traces. ${ }^{37}$ Yet, except for this extremely poor group, most people will have lived in houses. In some of the larger houses in Pompeii specific places for slaves have been found. ${ }^{38}$ Small shop owners slept in their shops, or above them, and may have lived in crowded circumstances where a family was involved. The extent to which a city was overcrowded is hard to determine. It may involve too much speculation to draw parallels with the number of people per house in Egypt, which is reasonably well documented from the papyri. Hobson has argued, for instance, that the Egyptian concept of home was quite different from ideas with which we are familiar. Family and village were regarded as integral units and might extend indefinitely. No compelling reason existed for persons to sleep at home with the rest of the family, as outside was equally 'home' ${ }^{39}$ Wallace-Hadrill refrains from any estimation of the population of Pompeii on the basis

35 CIL 4.138 and 4.1136. See Wallace-Hadrill, 'Houses and Households', 218-20, and especially Pirson, 'Rented Accommodation', for an extended discussion with detailed maps of the two relevant insulae.

36 Williams and Zervos describe the rooms of the upper floor as 'more than a cubiculum', and mention that one room may possibly have been used also for storage for the shop, given the large number of storage jars ('Corinth, 1985', Hesperia 55 [1986], 140).

37 The evidence for how widespread this was is, however, very scarce. Meggitt mentions inter alia the testimony of Dio Chrysostom, who talks about the shanties of his native city, Prusa (Orat. 40:8-9). However, in that passage, Dio is defending his programme of modernising the Bithynian city and calls the old workshops 'shanties', clearly with rhetorical exaggeration. This underlines the silence of literary sources on the very poor.

38 Wallace-Hadrill, 'Houses and Households', 222.

39 Deborah W. Hobson, 'House and Household in Roman Egypt', in Yale Classical Studies XXVIII, Naphtali Lewis ed. (Cambridge: CUP, 1985), 228-29. 
of numbers per hectare based on a comparison with e.g. mediaeval cities; ${ }^{40}$ others boldly assume certain figures for a Roman city. 41

It has been argued that the function of rooms of a Roman house were not static but dynamic, having different functions at different times of the day. ${ }^{42}$ This means that one cannot take the number of sleeping rooms as an indicator of how many people lived in the house. Most rooms could be used as a place to sleep.

\section{Spectrum of House-Types}

As can clearly be seen in Pompeii, a whole spectrum of house-sizes and types existed. This strongly suggests that there were various needs and also various economic possibilities. At one end of this spectrum we find the large houses built around an atrium. But next to this category we find a whole array of house types and sizes. It seems obvious that larger houses, with more rooms and working space, would have been charged out at a higher rent than the small cenacula above shops. Given these differences in available housing space, one is led to assume 'economic differences' among the non-élite: one person was able to spend more on rent than another.

Despite the paucity of material, it can be ascertained that a variety of housing did exist in Corinth. We have the villas signalling the presence of the upper class, and we have the shops and domestic structures east of the theatre. The shops (buildings 1 and 3) are of a similar plan with probably a second floor above them but with only a few rooms. The small unit formed within building 5 displays an apartment at the lower end of the spectrum, while building 7 belongs to a higher position in the range of housing, though nothing can be said about the plan of its second floor. The fact that wall-painting was found in buildings 3,5 , and 7 reflects the fact that apparently their occupiers could afford themselves some level of luxury.

The housing evidenced in Corinth betrays the existence of distinctions in Meggitt's 'non-élite class' that go beyond his distinction between 'the poorest' and 'the marginally economically more successful'. The range of housing seems to indicate the

\footnotetext{
40 Wallace-Hadrill, 'Houses and Households', 199-203.

41 Engels (Roman Corinth, 81-84) comes to 160 people per hectare for Corinth. Meggitt (Paul, Poverty, 71 n. 174) cites MacMullen for the figure of 'approaching 200 per acre' ( $=$ almost 500 people per hectare).

42 Joanne Berry, 'Household Artefacts: Towards a Re-interpretation of Roman Domestic Space', in Domestic Space in the Roman World: Pompeii and Beyond, Ray Laurence and Andrew Wallace-Hadrill, eds. (Portsmouth, R.I.: Journal of Roman Archaeology, 1997), 194-95.
} 
existence of a 'middle class' whose absolute wealth cannot be ascertained but who could afford themselves some kind of luxury and have to be distinguished from the very poor. Though the archaeological evidence suggests that this group was present in the city of Corinth, no conclusions can be drawn on the basis of the materials presented above as to whether this middle class was present in the church. However, a close look at Paul's Corinthian correspondence may reveal indications of the presence of the nonpoor in the church. First, in 1 Corinthians 1:26 Paul addresses the Corinthians thus: 'not many of you were powerful or of noble birth'. Though it is Paul's intention to say that most of his audience were not powerful, his careful formulation forbids the conclusion that all the church belonged to the very poor. Secondly, in 1 Corinthians 16 , we find the household of Stephanas described as having devoted itself to the service of the saints, and even as able to send messengers to Paul in Ephesus. Travelling for visiting purposes is unlikely to have been within the reach of the poor. Thirdly, Paul addresses also in 1 Corinthians 16 the issue of the collection for Jerusalem. It seems awkward that the apostle would ask a church that is struggling to provide even for its basic sustenance to help to alleviate the poverty of the Jerusalem church. A more natural background for such an exhortation is the availability of at least some means of complying with Paul's request.

The variety of housing in Corinth shows us a society which cannot be simply divided into an élite and a very poor non-élite. The non-élite were not all extremely poor nor did all lead a life just above abject poverty. Such generalisations are not supported by the archaeological evidence and cannot be used in describing Paul's relation to the wealthy and the poor in Roman society. 